Brit. J. industr. Med., 1957, 14, 73.

\title{
THE HEALTH OF THE WORKER*
}

\author{
BY \\ P. A. B. RAFFLE \\ From the Medical Department, London Transport Executive
}

The health of the worker must nowadays be considered against a background of improved social conditions, of death rates which have fallen continuously for a century, and of a reduction in communicable diseases.

At one time industrial medicine was preoccupied with the direct and demonstrably harmful effects of certain occupations on health (Schilling, 1956). Now that many of these situations have been brought under control, it can be concerned with the many physical and psychological factors of work which may influence health.

\section{Lord Horder (1956) wrote:}

"The relations between health and industry may be thought of in terms of a two-way track. Advances in the science and art of medicine can be of great service to industry if properly applied, and industry can make very useful contributions to medicine by studying the environmental conditions of large groups of workers and the influence of these conditions upon the health of the individual."

This is a concept which would have appealed to Sir Edwin Chadwick, that great pioneer, who used all methods and materials in his fight to improve the health of the community.

\section{THE CONTRIBUTION OF MEDICINE TO INDUSTRY}

It is accepted that a healthy working community is happier and more productive than a less healthy one. Yet only the haziest ideas exist of what is meant by health. The World Health Organization (1948) produced the somewhat ponderous definition, which has not yet been bettered, that " health is a state of complete physical, mental, and social wellbeing and not merely the absence of disease or infirmity". Health as thus defined cannot be measured. But the absence of health, i.e., sickness, can be studied clinically and absence from work due to sickness can be measured statistically.

* A public lecture delivered under the auspices of the Chadwick Trustees, on November 22, 1956, and published with the approval of the Trustees.
The Use of Sickness-absence Statistics

In the study of health, it is necessary to supplement clinical impressions by measuring and comparing the amount of sickness among large groups of workers and so discovering whether different occupations produce different patterns of disease. One method is to study the rates of absence from work attributed to sickness. Reflected in these rates are not only illnesses, but also the reactions of people to their working environment, to the morale of the group in which they work, and to their social adjustment inside and outside the factory.

Among the many factors affecting absence from work attributed to sickness are the nature of the work, the degree of physical fitness required in order to undertake it, the environmental working conditions, the quality of supervision, the regulations concerning National Insurance benefits, the provision of sick pay, and all the effects on the individual of his social life outside the factory. As one direction of the two-way track, industry expects help from its doctors in unravelling these factors and in drawing attention to those which management can alter.

With so many possible factors to consider, it is not surprising that progress in this work has been slow. Because there was no information on the sickness-absence experience of the general population which could be used as a base-line for comparing occupational groups, industry had to construct its own base-line by collecting the information about large groups of employees for a number of years. An example of this is the recent publication of Health in Industry (London Transport Executive, 1956), a book which gives sickness-absence data for large groups of London Transport staff.

Variables Affecting Sickness-absence Rates.There are three well-known but important variables which must be taken into account when comparing the sickness-absence rates of groups: age, whether the absence is short and uncertificated or long and supported by a medical certificate, and sex.

Age.-The graph of the annual average duration 


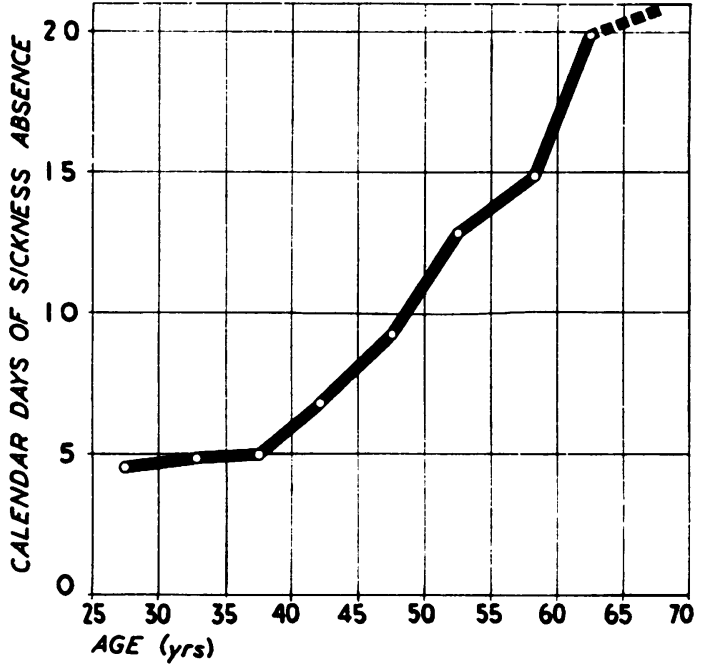

FIG. 1.-London Transport Executive central bus drivers 1949-52: average annual duration of absence per person from all causes (absences of four to $\mathbf{1 8 2}$ days' duration).

The average annual duration of sickness absence $=$ the average number of calendar days of sickness per person per year.

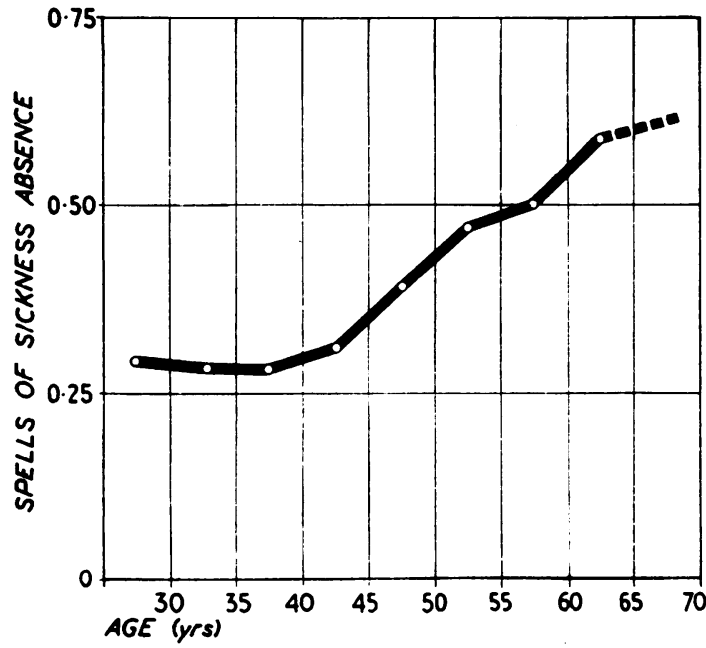

Fig. 2.-London Transport Executive central bus drivers 1949-52: annual inception rate (spells) of absence from all causes (absences of four to 182 days' duration).

The annual inception rate (spells) $=$ the average number of spells of sickness absence beginning per person per year.

of absence attributed to sickness for London Transport bus drivers is a typical example (Fig. 1) of the effect of age. The rate stays fairly constant at just under five calendar days per man per year up to the age-group $35-40$, then rises steeply until at the age of $60-65$ the rate reaches four times this figure.*

* Absences lasting more than six months are curtailed at 182 days' duration (London Transport Executive, 1956).
The annual inception rate (Fig. 2), that is, the average number of spells of sickness per man per year, shows that the increase is about twofold over the same age range. The older men take about twice as long to recover from each of their illnesses as the younger men, the average length of absence per spell rising from 15 calendar days at the ages of 25-29 to 33 days at 60-64. This general pattern is seen in most of the groups of men studied, though there may be variations in the steepness of the slope. The same pattern is also common in individual diseases or groups of diseases, though there are some exceptions, notably in infectious conditions which tend to give higher rates at the younger ages. Thus any statistics which do not take into account the age structure of the group being studied can give very misleading results.

Short-term Absences.-When short-term, uncertificated absence attributed to sickness is studied, an entirely different picture is seen. Short-term absence is conveniently defined as absences of one, two or three days' duration. The graph of the average number of spells of this duration per year in London Transport drivers (Fig. 3) shows that the rate at the younger ages is nearly twice that of the older men. There may be at least three influences at work here. First, these short-term absence rates may be an index of morale and stability in a group. An older driver with more domestic responsibilities than a younger man is perhaps less likely to take

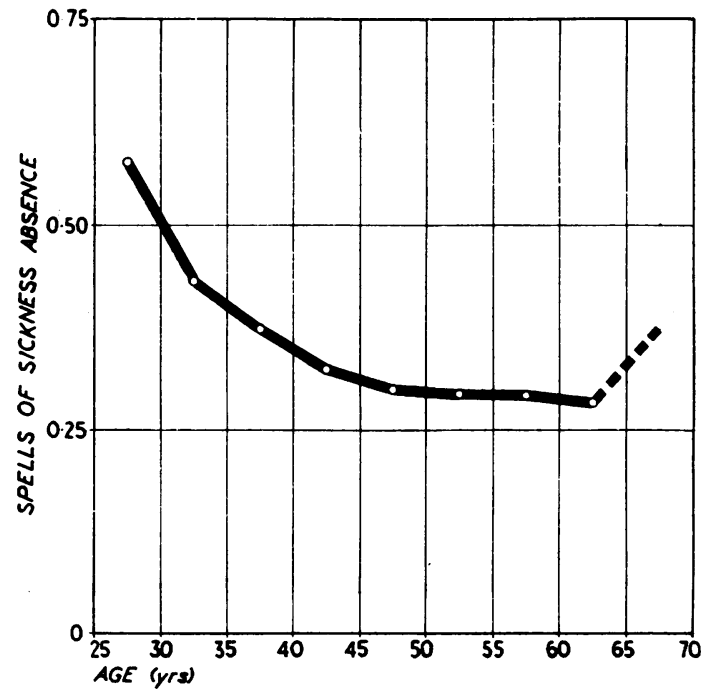

Fig. 3.-London Transport Executive central bus drivers 1949-52: annual inception rate (spells) of absence from all causes (absences of one to three days' duration).

The annual inception rate (spells) $=$ the average number of spells of sickness absence beginning per person per year. 
single days off, even when he is not feeling well. Second, as younger men recover from sickness more quickly than older men, they will tend to have more sickness spells of short than of long duration. Third, the common cold, a frequent cause of short-term absence, probably contributes to the higher rate of the younger men. Young people may not have as much immunity to colds as older people because they have not had the opportunity to be infected by so many different strains of virus. In still older age groups more complications of the common cold, especially bronchitis, can be expected, and therefore long absences are more likely than short ones. Some support is given to this view when the figures for long-term absences due to colds and influenza are studied. The rates tend to be high at the younger ages, fall in the middle years, and rise again at the older ages. And it is also of interest to note that the seasonal variations of shortterm absences follow closely the seasonal variations of long-term absences attributed to respiratory diseases and to all causes.

Sex.-The sickness-absence rates for women differ markedly from those for men. The tendency is for the average number of spells per woman per year to remain fairly constant throughout working life, or even to fall slightly at the older ages. The average number of days of absence per woman per year rises with increasing age, but not to the same extent as with men. Thus the younger women experience a larger number of absences of shorter duration than the younger men. This difference is not accounted for by the diseases peculiar to women.

Women as a whole have higher rates of absence attributed to sickness than men and there is also considerable difference depending on their civil state.* A convenient method of comparing the sickness-absence experience of two occupational groups is to compare the actual recorded sicknessabsence of the first group with what that group would be " expected " to have if it had the experience of the second group, making due allowance for the age-distributions of the two groups; the results are expressed as a percentage of the figures "expected" (London Transport Executive, 1956). Table 1 shows (in round figures) the comparison, by this method, of the experience of single and married women clerical staff with that of male clerical staff. Single women have more absence than men (for instance, they have $65 \%$ more shortterm absences than would be expected at the men's

\footnotetext{
* Civil state can mean no more than whether they call themselves “ Miss" or "Mrs.". It is unlikely that the employer has more detailed information than this about their personal lives and home responsibilities; for instance, a "married" woman may be widowed, divorced, or separated.
}

TABLE 1

SICKNESS-ABSENCE RATES 1950-52 FOR ALL CAUSES IN LONDON TRANSPORT WOMEN CLERICAL STAFF*

\begin{tabular}{|c|c|c|c|}
\hline & \multirow{2}{*}{$\begin{array}{c}\text { 1-3-Day Absences } \\
\text { Spells per } \\
\text { Annum (\%) }\end{array}$} & \multicolumn{2}{|c|}{ 4-182-Day Absences } \\
\hline & & $\begin{array}{l}\text { Spells per } \\
\text { Annum (\%) }\end{array}$ & $\begin{array}{c}\text { Days per } \\
\text { Annum (\%) }\end{array}$ \\
\hline $\begin{array}{l}\text { Single women } \\
\text { Married women }\end{array}$ & $\begin{array}{l}165 \\
210\end{array}$ & $\begin{array}{l}170 \\
200\end{array}$ & $\begin{array}{l}180 \\
225\end{array}$ \\
\hline
\end{tabular}

*Actual figures compared with " expected" figures based on experience of male clerical and technical staff.

rates) and married women have more absence than single women (London Transport Executive, 1956). As a rough guide, for clerical staff long-term absences attributed to sickness in men, single women, and married women occur in the ratio $1: 1 \frac{3}{4}: 2$.

When bus conductors are considered, single women have twice the sickness-absence rates of the men and married women three times the men's rates.

Further Factors Affecting Sickness-absence Rates.It follows that before any valid conclusions can be drawn from comparing sickness-absence experience between groups, at least their age structure, the proportion of long and short absences and the proportion of men, single and married women, must be known. Even then other precautions must be taken, such as to study large groups so that chance variations do not play too important a part in the overall pattern; to avoid basing deductions on one year's experience (this can be full of pitfalls because there are years when epidemics of colds and influenza have a marked but varying effect on the experience of different groups; when several years' figures are added together a much more reliable picture of the groups is given); and to know what factors are affecting the selection of the persons in the group, their recruitment into the group, their continuance as a member of the group (which is in itself a form of selection), and their reasons for leaving the group, be it promotion, voluntary resignation, age retirement, employer's opinion on ability, or physical fitness for the work.

\section{The Accuracy of Diagnoses Related to the Validity of Sickness-absence Statistics}

Some people question the value of sicknessabsence statistics on the grounds that the diagnoses on the medical certificates from which the statistics are built up vary greatly in their accuracy and precision. This view ignores the basis of the use of these statistics, which is the comparison of the experience between occupational groups to discover whether different occupations produce different disease patterns. The precision and accuracy of the diagnoses recorded for one occupational group 
should not differ sufficiently from those recorded for another occupational group to invalidate the comparison between the groups. The presence or absence of a difference in sickness-absence experience between occupational groups demonstrates whether or not there is a health problem in one of them which should be investigated by one or more of many other methods of enquiry.

\section{The Value of Sickness-absence Statistics}

Determining Frequency of Hernia.-A simple example of the value of sickness-absence rates is that they answer questions about the frequency of hernia in bus drivers. "Straining at the wheel" was a commonly heard phrase and the implication was that the drivers suffered unduly from ruptures. This is a diagnosis which could be expected to be recorded precisely. The clinical impression among the doctors working in London Transport was that the rate among drivers was not unduly high compared with the general population, and that this was to be expected because the inguinal canals would be protected by the flexed thighs when driving. Although drivers have, age for age, $82 \%$ of the average number of spells of sickness-absence per person per year that conductors have for all causes, they only have $60 \%$ of the conductors' experience for hernia (London Transport Executive, 1956). There do not seem to be any fallacies in comparing these two groups of men who differ only in the work they do except-to be mentioned later-that men of different physique may select themselves for the two jobs and different physiques may predispose to different chances of developing a hernia. However, the point was made that drivers' experience of this condition was more favourable than had been thought.

Evaluating Relationship between Responsibility and Sickness.-The relationship between responsibility and exacting duties and sickness is attracting attention to-day. It is a difficult subject to study because the number in responsible positions is comparatively small and there is a large element of selection involved; only certain types of men reach the higher grade posts. In London Transport garages there are officials who correspond to the departmental managers in other organizations. They are responsible for the staffing of all the buses which run from their garage and they have to deal with the administration and discipline for any number between 300 and 1,200 men and women. They certainly can be considered to carry heavy responsibility. They are mainly ex-drivers and conductors who have been gradually promoted to their present positions. Their sickness-absence experience is interesting
TABLE 2

SICKNESS-ABSENCE 1952-54 FOR ALL CAUSES IN LONDON TRANSPORT GARAGE OFFICIALS*

\begin{tabular}{|c|c|c|c|c|}
\hline \multirow{2}{*}{$\begin{array}{c}\text { Garage } \\
\text { Officials } \\
\text { Compared } \\
\text { with }\end{array}$} & \multirow{2}{*}{$\begin{array}{c}1-3-D a y \\
\text { Absences } \\
\text { Spells per } \\
\text { Annum (\%) }\end{array}$} & \multicolumn{3}{|c|}{ 4-182-Day Absences } \\
\hline & & $\begin{array}{c}\text { Spells per } \\
\text { Annum (\%) }\end{array}$ & $\begin{array}{c}\text { Days per } \\
\text { Annum (\%) }\end{array}$ & $\begin{array}{l}\text { Days per } \\
\text { Spell }(\%)\end{array}$ \\
\hline $\begin{array}{l}\text { Bus drivers } \\
\text { Male clerical } \\
\text { and technical } \\
\text { staff }\end{array}$ & 50 & 80 & 100 & 140 \\
\hline
\end{tabular}

*Actual figures compared with " expected" figures based on the experience of bus drivers and of male clerical and technical staff.

(Table 2). When their experience age by age is compared with that of drivers, from which grade many were promoted, they are found to have less short-term absence; of long-term absence they have fewer spells and the same average number of days per person per year and more average length of absence per spell. When these officials are compared with male clerical and technical staff, who have broadly the same sick pay and leave entitlements, they are found to have even fewer one- to three-day absences, and of long-term absences about the same number of spells, a higher annual average duration and average length of absence per spell. Though the figures on which these results are based are small, they suggest a picture of a group of men who have been selected because of their ability, loyalty, and hard work and who work on during the minor illnesses for which other men would take time off and who, when they do have an illness, take longer to recover, like a fly-wheel which is hard to stop and equally hard to start up again. This is obviously a group of men which an industrial medical service should watch, especially now that the figures have supported the clinical impression which initiated the investigation.

Checking Level of Sickness-absence in an Office.Another example of the use of sickness-absence statistics to ascertain the facts of the situation occurred when a question was asked whether the amount of sickness among the girls in a typing pool was abnormally high. Arguing from first principles, it would not be surprising if the rates in a large typing pool were higher than in the remainder of women clerks, because environmental conditions in large offices are usually less satisfactory than those in small offices. For example, ventilation without draughts is more difficult to arrange; adequate heating for all without overheating those at the periphery of the office is difficult to provide; dependence on artificial lighting rather than daylight for a large percentage of the staff is more common; and noise and the visual disturbance of 
many people moving around are more noticeable in large offices than in small. Infectious diseases may be transmitted more widely among people working in large workshops or offices than among the same number of people working in a number of small offices or shops.

With all these factors weighing in favour of an above-average sickness-absence experience in the typing pool, the fact was that, during the three years 1950-52, the typists' rates, for spells and for durations, for short and for long absences, did not differ by more than $2 \%$ from those "expected" on the basis of the generality of women clerks. To show that these girls were having the same sickness-absence rates as were expected from their age and marital status was a negative finding of value, because any apprehension felt by the girls or by management was thereby allayed.

\section{THE CONTRIBUTION OF INDUSTRY TO MEDICINE}

There are probably three conditions which are exercising the minds of those responsible for preventing ill-health in the community more than any others-bronchitis, coronary heart disease and cancer of the lung.

\section{The Study of Bronchitis}

The study of bronchitis is a subject in which industry can help a great deal, and information from this source is beginning to accumulate (Roberts and Reid, 1954; Gregory, 1955; Reid, 1956). Industry can provide figures to compare the bronchitis experience of large groups of people in different occupations; certain ideas of the causation and natural history of the disease can be developed from these data. It is a complex problem, not least because of the difficulty of defining what is meant by "bronchitis" and because of the number of factors which may influence this condition. For instance, why do bus conductors experience, age for age, $130 \%$ of the annual average days of absence and $145 \%$ of the average number of spells of absence that bus drivers have from " bronchitis"? Is it because a conductor is more disabled by a mild attack from running up and down the stairs than the driver is from driving the bus, and therefore is less likely to come to work ? Or is it because conductors have $130 \%$ of the long-term absences from colds and influenza that drivers have, and, because the rate is particularly high at the younger ages $(150 \%$ or more), the respiratory system of conductors is more damaged by these infections and made more liable to attacks of bronchitis in later years? Or is it because drivers and conductors are different types of people in any case ?
It has recently been shown that they differ in at least one aspect of physique. These are some of the questions that those interested in preventive medicine must answer before it is possible to formulate methods of preventing a disease which accounts for $11 \%$ of the total sickness-absence of many groups of workers (London Transport Executive, 1956).

\section{Coronary Heart Disease}

Morris and Raffle (1954) and Morris, Heady, Raffle, Roberts, and Parks (1953) showed that bus drivers had more coronary heart disease than bus conductors and what they had was more severe. Thus the mortality rate, age for age, for drivers in the first three days, first three months, and first three years, after the first clinical episode of coronary ischaemic heart disease, was twice that of male conductors. Drivers and conductors are similar groups of men in most respects; they live in the same areas, generally near their garages, their wage is much the same, and they come from the same group of the community. Where they differ is in the work which they do. One of the respects in which their work differs is in the amount of physical activity in driving a bus and conducting it. This led Morris et al. (1953) to study other occupations and a similar relationship was found. Men whose work involved physical activity had a better experience from coronary heart disease than those whose work was more sedentary.

Lack of physical activity is one of many factors possibly concerned in the aetiology of coronary heart disease. Others include the amount and type of fat in the diet, the amount smoked, the race and the social class from which the person is drawn, and the amount of responsibility accepted. One further factor which has been observed to affect the incidence of coronary thrombosis is constitution as reflected in body shape (Gertler and White, 1954). Morris, Heady, and Raffle (1956) therefore compared the sizes of uniform of a sample of London Transport bus drivers with those of male conductors. It was immediately apparent (Fig. 4) that at all ageseven at 25-29 before occupation could have caused the difference-bus drivers measured more round the waist than conductors, after due allowance had been made for height. When chest measurements were compared, the same feature was found. It was also shown (in a much smaller sample) that those drivers who had joined London Transport as conductors and had been promoted to drivers after training and those who had joined as drivers and therefore had previous driving experience, were both bigger than conductors, even at the youngest ages.

More work will be necessary to show whether there is a relationship between the different shape 


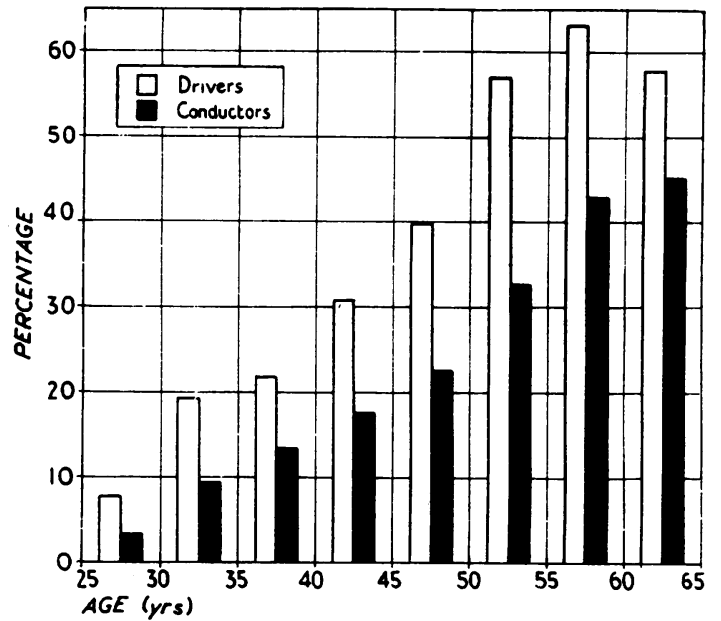

FIG. 4.-Comparison of London Transport Executive drivers and male conductors, 1954: percentages of sizes of uniform greater than 36 in. waist measurement (adjusted to take height into account).

of drivers and conductors and their different experience of coronary heart disease. It has, however, been clearly shown that industry can provide data for medical research which are not available from other sources. It has also been shown that self-selection or selection by the operation of other factors can vary the composition of groups of workers to an extent which cannot be predicted. One of the questions immediately posed is: "Is the difference in physique between drivers and conductors related to the difference in the psychology between them which makes one group wish to drive and the other to conduct ?" The demonstration of such a relationship would be of fundamental value to medical research.

\section{Cancer of the Lung}

The increase in the incidence of cancer of the lung in the population has had considerable publicity, especially since two probable causes of the increase have been demonstrated. Work in this country and elsewhere has shown beyond reasonable doubt that there is a relationship between cancer of the lung and heavy cigarette smoking. There is also some ingredient in the air of towns which predisposes to the development of the condition. The urban death rates from cancer of the lung are consistently higher than the rural rates, and Stocks and Campbell (1955) showed that this still applies when allowance is made for differences in smoking habits.

One of the constituents of the air of towns which has been suggested as being responsible is the exhaust gases from diesel engines. Kotin, Falk, and
Thomas (1954) demonstrated that the exhaust gases of petrol engines contain 3:4-benzpyrene and other polycylic hydrocarbons which are known to produce cancer when painted on the skin of mice. Later work by Kotin et al. (1955) indicated that benchrun diesel engines only produced 3:4-benzpyrene when badly maintained or adjusted.

In view of its importance to the health of urban dwellers, this problem was investigated from two aspects. The chemical composition of the exhaust products of the diesel engines of moving buses was investigated and a study made of the incidence of cancer of the lung among various groups of London Transport staff.

Commins, Waller, and Lawther (1956) in an interim report showed that, although the concentration of smoke was greatly increased during periods of intense vehicle activity in a diesel bus garage, there was no increase in the concentration of $3: 4-$ benzpyrene, which remained very similar to that of the outside air. They also showed, by direct estimation, that the exhaust products of diesel buses contain no 3:4-benzpyrene when the engines are in average condition and very little, if any, when they exhibit some abnormality.

During the course of this investigation, a preliminary study of the lung cancer rates among London Transport staff was undertaken. The numbers of cases were very small and the deductions, therefore, can only be tentative. It was decided to include not only deaths, but also retirements from the service and transfers to alternative work on account of ill-health, due to lung cancer. The inclusion of retirements and transfers may weight the figures unfavourably in comparison with the national death rates by including recovered cases, but the exclusion of such cases would have made the figures artificially favourable by ignoring cases dying after leaving the service, or after transfer to other work.

It was assumed that engineering staff working in bus garages had a greater exposure to exhaust gases than any other group of staff, and that, if any carcinogen be present in the gases, their experience of cancer of the lung would be worse than that of the general population and worse than that of other men in London Transport.

Table 3 gives the crude rates for deaths, retirements due to ill health, and transfers to alternative work for various groups of men aged 45-64 during the years 1950-54. In Table 3 the groups of staff are arranged in the order of increasing exposure to exhaust fumes (based on general observation and not chemical estimation). Though the rates are not corrected for age within the age range $45-64$, as has been done with the other figures so far presented, 
TABLE 3

DEATHS, ILL-HEALTH RETIREMENTS, AND TRANSFERS TO ALTERNATIVE WORK DUE TO LUNG CANCER IN LONDON TRANSPORT MALE STAFF AGED 45-64

\begin{tabular}{|c|c|c|c|}
\hline \multirow{2}{*}{ Group of Staff } & \multirow{2}{*}{$\begin{array}{c}\text { Exposed } \\
\text { to Risk } \\
\text { (man years) }\end{array}$} & \multicolumn{2}{|c|}{$\begin{array}{l}\text { Deaths, Ill-Health Retire- } \\
\text { ments and Transfers to } \\
\text { Alternative Work } 1950-54\end{array}$} \\
\hline & & Number & $\begin{array}{c}\text { Annual Rate } \\
\text { per } 1,000\end{array}$ \\
\hline $\begin{array}{l}\text { Motormen and guards } \\
\text { (L. railways) }\end{array}$ & 8,253 & $11(10) \dagger$ & $1 \cdot 3$ \\
\hline $\begin{array}{l}\text { Engineering staff } \\
\text { (trolleybus depots) }\end{array}$ & 5,529 & 10 & 1.8 \\
\hline $\begin{array}{l}\text { Engineering staff } \\
\text { (Chiswick Works) }\end{array}$ & 9,979 & 12 (12) & $1 \cdot 2$ \\
\hline \multirow{2}{*}{$\begin{array}{l}\text { Central bus drivers } \\
\text { Central bus conductors } \\
\text { Engineering staff } \\
\text { (bus garages) }\end{array}$} & $\begin{array}{l}33,466 \\
16,978 \\
18,140\end{array}$ & $\begin{array}{ll}23 & (17) \\
18 & (15) \\
22 & (21)\end{array}$ & $\begin{array}{l}0 \cdot 7 \\
1 \cdot 1 \\
1 \cdot 2\end{array}$ \\
\hline & $\begin{array}{l}\text { Male } \\
\text { Population* } \\
\text { Aged 45-64 }\end{array}$ & $\begin{array}{l}\text { Deaths } \\
1950-53\end{array}$ & \\
\hline $\begin{array}{l}\text { England and Wales } \\
\text { Greater London }\end{array}$ & $\begin{array}{r}19,947,000 \\
3,834,000\end{array}$ & $\begin{array}{r}26,689 \\
6,292\end{array}$ & $\begin{array}{l}1 \cdot 3 \\
1.6\end{array}$ \\
\hline
\end{tabular}

* Obtained by adding the populations given in the RegistrarGeneral's statistical reviews for the years 1950-53 inclusive.

+ Deaths in brackets.

it can be said that, in each group of staff, the proportion of men in each of the age groups, 45-54 and 55-64, were the same as in the general population of England and Wales, except that in both the bus and trolleybus engineering staff there was a higher percentage in the older age group. This should have made their experience even more unfavourable, because the incidence of the disease in the general population increases with age, at least until the age of 65 .

Even though the figures are small, the rates do not differ greatly from the death rates in England and Wales and in Greater London; in fact, with one exception, they are lower than the experience of the general population. There is certainly nothing resembling the twelve-fold difference between non-smokers and smokers which Doll and Bradford Hill (1956) report. No excess is shown in the bus engineering staff, where an excess would have been expected if diesel exhaust fumes contained a carcinogen which was active on human lungs.

The figure for the trolleybus engineering staff is the highest, although this group of staff is less exposed to exhaust fumes than any except the railwaymen. Stocks (1952) found that the cancer of the lung death rates were highest in the boroughs in the east of London. He demonstrated that there was a close correlation between this death rate and the density of population, but that the prevailing wind from the south-west also had an effect. A high proportion of the trolleybus depots are in the north-east of London, and it seemed possible that this might explain the high figure for the trolleybus engineering staff.
It was, therefore, decided to combine the figures for the bus and trolleybus engineering staff, to distribute the deaths between the four segments of London according to the place of work (which is also very similar to the residential area), and to compare the actual death rates in these four areas with what would have been expected if these men had had the experience of London Transport male wages staff of all grades. Table 4 gives the results for men aged 55-64 during the years 1950-55. The

TABLE 4

DEATHS DUE TO LUNG CANCER 1950-55 IN LONDON TRANSPORT BUS AND TROLLEYBUS ENGINEERING STAFF (MEN AGED 55-64)

\begin{tabular}{|c|c|c|c|c|c|}
\hline \multirow[b]{2}{*}{ Area } & \multirow[b]{2}{*}{$\begin{array}{c}\text { Exposed } \\
\text { to Risk } \\
\text { (man } \\
\text { years) }\end{array}$} & \multicolumn{2}{|c|}{ Actual Deaths } & \multirow[b]{2}{*}{$\begin{array}{l}\text { Expected } \\
\text { Deaths }\end{array}$} & \multirow[b]{2}{*}{$\frac{\text { Actual }}{\text { Expected }} \times 100$} \\
\hline & & Number & $\begin{array}{c}\text { Annual } \\
\text { Rate } \\
\text { per } \\
1,000\end{array}$ & & \\
\hline $\begin{array}{l}\text { North-west } \\
\text { North-east } \\
\text { South-west } \\
\text { South-east }\end{array}$ & $\begin{array}{l}4,269 \\
4,780 \\
3,432 \\
3,514\end{array}$ & $\begin{array}{r}7 \\
11 \\
4 \\
8\end{array}$ & $\begin{array}{l}1 \cdot 6 \\
2 \cdot 3 \\
1 \cdot 2 \\
2 \cdot 3\end{array}$ & $\begin{array}{l}5 \cdot 66 \\
6 \cdot 27 \\
4 \cdot 54 \\
4 \cdot 70\end{array}$ & $\begin{array}{r}123.7 \\
175.5 \\
88.1 \\
170.2\end{array}$ \\
\hline
\end{tabular}

* The expected deaths are calculated from the experience of London Transport male wages and supervisory staff aged 55-64 in 1950-53.

highest ratios of actual/expected deaths are in the north-east and south-east segments and the lowest in the south-west segment. This is what would be expected from the theory that the amount of a carcinogen in town air depends on the density of population (possibly the number of coal fires) and that it is also driven by the prevailing wind.

It has been stressed that the number of cases involved in this investigation is small. Confirmation of the geographical effect noted amongst the engineering staff was sought but was not obtained from the figures for bus drivers and conductors who, though they travel back and forth across London, generally live near their garages and are therefore subjected to the environmental influences of their residential area. It was found that those drivers and conductors whose garages were situated in the south-west of London had the worst experience and those in the north-west the best. Thus all that can be said, on the basis of the small figures so far available, is that there is no excess of lung cancer among any group of London Transport staff such as would have been expected if diesel exhaust fumes were a serious contributory factor in producing an excess of lung cancer in urban dwellers.

\section{THE TWO-WAY TRACK}

It will thus be seen that the study of the health of the worker is a two-way track. Industry is making use of the art and science of medicine in endeavouring to discover whether, in fact, certain common 
occupations affect the health of those employed in them and, if so, what measures are likely to prevent such effect. In its turn, medicine is benefiting by the generous way in which industry, particularly the large organizations, is collecting and making available data which are of considerable value to medical research.

\section{SUMMARY}

The study of the health of the worker is described as a two-way track. The contribution of medicine to industry is exemplified by the use of sicknessabsence statistics. The factors influencing sicknessabsence rates in occupational groups are discussed and examples are given of the value of these rates in investigating specific health problems.

The contribution of industry to medicine is illustrated by the use which is made in medical research of data collected in industry. The value is discussed of these data in the investigation of bronchitis, coronary heart disease, and cancer of the lung. The incidence is given of cancer of the lung in groups of London Transport staff which have varying exposure to diesel exhaust gases.

I wish to thank the London Transport Exezutive for permission to publish this paper and to use the material on which much of it was based. I also wish to record my deep appreciation to many colleagues who have given much help and encouragement, especially Dr. L. G. Norman, Chief Medical Officer, Mr. F. H. Spratling, F.I.A., and Mr. C. J. Cornwall, F.I.A.

It is probably only in the large industries that it is possible to study large enough groups of people doing the same work to make detailed analysis worth while. Also it is unusual for medical departments to have the staff to undertake the task of collecting, sorting, and tabulating the mass of data involved. Those of us who have the opportunity to do this work are deeply indebted to our colleagues, actuaries, and statisticians, for making available to us this wealth of material.

\section{REFERENCES}

Commins, B. T., Waller, R. E., and Lawther, P. J. (1956). Brit. med. J., 2, 753 .

Doll, R., and Hill, S. Bradford (1956). Ibid., 2, 1071.

Gertler, M. M., and White, P. D. (1954). Coronary Heart Disease in Young Adults. Harvard University Press, Cambridge, Mass.

Gregory, J. (1955). Trans. Ass. industr. med. Offrs, 5, 2.

Horder, Lord (1956). Health in Industry: A Contribution to the Study of Sickness Absence: Experience in London Transport, 1956, of Sickness Absence: Experience in London Transport, 1956,

Kotin, ${ }_{\text {P., }}^{1}$ (Folk, H. L., and Thomas, M. (1954). A.M.A. Arch. industr. Hith, 9,164 .

London Transport (1955). Ibid., 11, 113

London Transport Executive (1956). Health in Industry: A Contribution to the Study of Sickness Absence: Experience in London Transport, 1956. Butterworth, London.

Morris, J. N., and Raffie, P. A. B. (1954). British Journal of Industrial Medicine, 11, 260.

- - Heady, J. A., and Raffle, P. A. B. (1956). Lancet, 2, 569. , Roberts, C. G., and Parks, J. W. (1953). Ibid., 2,

Reid, D. D. (1956). Proc. roy. Soc. Med., 49, 767.

Roberts, C. G., and Reid, D. D. (1954). Brit. J. prev. soc. Med., 8, 147. Schilling, R. S. F. (1956). Mackenzie Lecture.

Stocks, P. (1952). Brit. J. Cancer, 6, 99.

W, and Campbell, J. M. (1955). Brit. med. J., 2, 923.

Worid Health Organization (1948). Official Records, No. 2. (Proc. International Health Conference, New York, 1946, p. 100.) 